\title{
Is Twitter an effective pedagogical tool in higher education? Perspectives of education graduate students
}

\begin{abstract}
Krishna Bista ${ }^{1}$
Abstract: This study presents the perspectives of education graduate students of using Twitter as a pedagogical tool for 15 weeks as a required social media activity in class. The results indicated that participants in each course reported a positive learning experience of using Twitter. Although this was their first experience with Twitter, participants reported that Twitter provided space and opportunities to engage in academic activities as a new pedagogical tool. Participants reported they used Twitter to receive immediate and frequent course information, ask questions to the mentor, update course assignments, and to share helpful information from outside the textbook with their fellow classmates and mentor. This study also highlights suggestions and implications for utilization of Twitter in personal and professional development.
\end{abstract}

Keywords: Twitter, student engagement, higher education, pedagogy, professional development, social media, graduate student

An important tool I learned to use this semester was Twitter. I would have never conceived that I would be discussing academics in the social media as we did. At first I was extremely uncomfortable using Twitter. Later, it became second nature and was easy. Twitter was a great way to stay abreast of what was going on in our class. Next semester, I will be like an old hand at Twitter!

(Annette Smith, MEd Special Education)

\section{Introduction}

Twitter is a social networking site that offers micro blogging services to interact via Twitter posts, also called tweets, on Smartphones, laptops, iPods, and any devices with Internet access. In the past few years, researchers have significantly studied online social networking sites (e.g., Facebook, Twitter, LinkedIn, and YouTube) to examine the relationship between educational outcomes and social networking (Bista, 2014; Gouseti, 2010; Kirschner \& Karpinski, 2010), student and faculty relationships (Malesky \& Peters, 2013; Veletsianos, 2012), and student engagement and social presence (Dunlap \& Lowenthal, 2009; Junco, Elavsky, \& Heiberger, 2013). Today, students and instructors are socially networked among their peers and friends. According to the Faculty Focus survey, 16.5 percent of higher education faculty out of 840 participants reported using Twitter daily compared to 44.6 percent of faculty using Facebook (Bart, 2011). Recent reports indicated Twitter is experimented as a classroom tool in high school (Antlfinger, 2014; Lang, 2013; Vooren \& Bess, 2013) and university classroom learning (Lin, Hoffman, \& Borengasser, 2013; McArthur \& Bostedo-Conway, 2012; Springer, 2014).

This study presents the perspectives of graduate students using Twitter as a pedagogical tool for 15 weeks as a required activity in the class. Is Twitter an effective teaching and learning

\footnotetext{
${ }^{1}$ Assistant Professor of Education, University of Louisiana at Monroe, bista@ulm.edu
} 
tool in higher education? What do students in the master of education programs say about their experiences of using Twitter in a semester long course? Are they going to use it as a personal and professional tool after the completion of the course?

\section{Literature Review}

\section{A. Twitter and Its Classroom Usage}

Launched in October 2006, Twitter has become an information networking tool that allows users to post a topic or a discussion no longer than 140 characters. Twitter includes several features for sharing information such as a timeline (chronological display of messages) and other settings, either private or public. In the past few years, professional learning communities have incorporated social media as pedagogical tools inside and outside the classroom (Bista, 2014; Blair, 2013; Rockinson-Szapkiw \& Szapkiw, 2011). A few studies show a significant positive role of social sites in communicating with students as a learning tool in the classroom (Aspden \& Thorpe, 2009; Junco, Elavsky, \& Heiberger, 2013; McArthur \& BostedoConway, 2012; Veletsianos, 2012).

Twitter, as an emerging social media, has been narrowly used in college classrooms across disciplines. Educators and practitioners do not recognize its value in terms of a teaching and learning tool. As indicated in the Faculty Focus (2009), more than half of nearly 2,000 faculty participants responded that they had never used Twitter. Of the total, 30.7 percent of faculty reported using Twitter, and less than half of them used Twitter to communicate with students. The remaining 12.9 percent of respondents said they tried Twitter in the past but no longer use it. The majority of participants who did not use Twitter questioned the educational relevance of Twitter, "expressed concerns that it creates poor writing skills," and expressed the fact that they did not know how to use Twitter or didn't have time to use it (Faculty Focus, 2009, p. 2).

The faculty who used Twitter reported a variety of reasons for using it: "to share information with peers," "as a real-time news source," instructional uses such as "to communicate with students" and "as a learning tool in the classroom" (Faculty Focus, 2010, p. 2). In a quantitative study, McArthur and Bostedo-Conway (2012) reported significant positive correlations between student Twitter-use and learning. The authors have recommended the use of Twitter for teacher-student interactions and lifelong learning experiences. While using Twitter among undergraduate and graduate students as an extra credit assignment, Lin, Hoffman and Borengasser (2013, p. 39) found that "students enjoyed being consumers of tweets but seldom retweeted or replied."

Educators have experimented with using Twitter in teaching a variety of courses including history, geography, business and language learning. For instance, Yuan (2012) used Twitter English writing and reading in a Taiwanese college. In another mixed method study, Luttrell (2012) examined the effectiveness of Twitter and other social medial in comprehension and application of public relation course material among undergraduate students.

The use of Twitter is suggested to enhance the social presence of students (Al-Khalifa, 2010; Dunlap \& Lowenthal, 2009; Lang, 2013). Social presence refers to the "ability of participants in a Community of Inquiry to project their personal characteristics into the community, thereby presenting themselves to other participants as "real people" (Garrison, Anderson, \& Archer, 2000, p. 89). In a study conducted at the University of Colorado at Denver, 
the instructors used Twitter to encourage their students to post in a variety of ways: to post questions and queries to one another, send student to student direct messages, share resources, link to student blogs, comment on conferences that their friends were attending, and exchange personal information (Chichester, 2010; Dunlap \& Lowenthal, 2009). The authors have reported that Twitter can enhance students" perceptions of a sense of "social presence" that helps promote student involvement, commitment, and retention. Because of its flexibility, the Twitter platform is also recommended as a virtual office (Al-Khalifa, 2010). Twitter enables students to participate in a wide range of interactions from private messages, to arranging meetings, and to engaging in learning processes (Al-Khalifa, 2010; Bista, 2014; Dunlap \& Lowenthal, 2009; McArthur \& Bostedo-Conway, 2012).

A few studies indicated the role of Twitter in establishing a collaborative learning relationship between students and instructors through the process of sharing ideas, resources and reflections (Blair, 2013; Ebner, Lienhardt, \& Meyer, 2010). In addition to classroom pedagogy, Salter (2012) has offered tips about using Twitter in the conference backchannels (i.e., include a Twitter handle on every slide, use Twitter-friendly links). Twitter enables conference participants and speakers to actively engage in discussion, since the users can tweet microfeedback and responses in real time (Priego, 2011). Beyond its use in marketing and recruitment, Twitter has grown its application in the classroom and professional development.

\section{B. Twitter and its Debate}

There is an ongoing debate among educators as to whether social media is an appropriate application for the classroom. Social media policies in the K-12 school setting and in the institutions of higher education vary in the United States. Some school teachers and faculty members have adopted a zero tolerance of social media policy, especially the use of Facebook and Twitter in the classroom whereas some are flexible regarding application of social media (Galagan, 2010; Lang, 2013; Metteson, 2010). Rockinson-Szapkiw and Szapkiw (2011) mentioned that Twitter encouraged students in "critical thinking, synthesis and evaluation throughout learning process" (p. 360). Research has reported positive relationships between Twitter use and student engagement where students used Twitter in educationally relevant and productive ways (Junco, et al., 2013; Junco et al., 2011).

Twitter may not be appropriate for all instructional situations based on the nature and demand of the courses. Grosseck and Holotescu (2008) have identified Twitter as timeconsuming, addictive, and possibly even a way to encourage bad grammar as a result of its 140character limit. In addition, students and faculty may be charged data fees if they access Twitter on their cell phones. For example, the online surveys that faculty want to connect to on their Twitter pages may require a subscription fee. Furthermore, participants in a study who used Twitter in the classroom have expressed frustration and anxiety (Faculty Focus, 2009). The faculty participants reported several negative comments about the use of Twitter such as, "It's mostly a waste of time and energy," "I have enough other ways to waste time," "It's beneath my dignity," and "I am sick of student writing that is unprofessional. I am also tired of receiving student work that has incomplete sentences, fragments, subject-verb agreement mistakes, point of views mistakes, tense mistakes" (Faculty Focus, 2009, pp. 5-6).

Although there are a few studies on how Twitter can be used for undergraduate students or whether faculty were interested or not interested in using the tool, there are not enough studies analyzing whether graduate students with an education major consider Twitter in their 
classroom or for their personal and professional development. What do graduate students in education programs (e.g., master of education in reading, educational leadership, curriculum and instruction, educational technology, special education, instructional leadership, and master of arts in teaching) who are currently teaching at schools or are administrators think about the use of Twitter? In this context, the current study aims to examine the perceptions of graduate students in education programs regarding the use of Twitter as a pedagogical tool. Therefore, this study aims to answer the following questions:

1. What are the perceptions and experiences of graduate students in education programs for using Twitter as a learning tool in a semester long course?

2. Do graduate students in education programs perceive Twitter as a classroom engagement tool in higher education?

3. How likely are these graduate students in education programs to use Twitter professionally within the next two years after the completion of the course?

4. Do graduate students in education programs recommend the use of Twitter in any future graduate classes?

\section{Research Method}

This study is a qualitative case study in nature. Yin (2013) defines the case study research method as an empirical inquiry that investigates a contemporary phenomenon within its real-life context. Case study is used to "examine contemporary real-life situations and provide the basis for the application of ideas and extension of methods" (Yin, 2013, p. 23). Researchers have defined a case as an object or entity (e.g., a student, a classroom) or an event (e.g., a campus protest) or a process (e.g., becoming a professional teacher) or a metaphor (Creswell, 2013; Johnson \& Christensen, 2014; Mertens, 2015; Yin, 2013). Case study is a research model within naturalistic research methodologies which allows researchers to investigate single or multiple units (Creswell 2012; Yin 2013).

This case study attempts to describe Twitter's use as a pedagogical tool among graduate students at one public university. It focuses on the process and results of having used Twitter among students. This case study design is an instrumental case study (see, Johnson \& Christensen, 2014, p. 436) where the primary interest of the researcher is in understanding student Twitter use in learning - how and why students use it and how effective they find it in their learning process. Johnson and Christensen (2014) said, "The instrumental case study is popular with many academic researchers when they are interested in generalizing and extending the findings in research literatures on various topics" (p. 436).

The researcher examined student written assignments from the selected courses. The researcher also examined 2,414 tweets collected from the course Twitter page, collected over the period of 15 weeks from the course participants. Participants engaged in the course Twitter Page from August through December of 2013.

\section{A. Participants and Contexts}

The participants were Twitter-using graduate students. Of 42 students included in the study, 31 were females, seven were males, and four did not identify their gender. The average age of participants was 34 years. All names of participants are pseudonyms to protect their confidentiality. The participants were enrolled in a required course in their master of education 
programs with various concentrations (e.g., educational leadership, curriculum and instruction, special education, elementary education, gifted and talented education, reading, and English as a second language). During the course, participants participated on the designated Twitter page for 15-weeks. Each participant posted at least two tweets weekly on the course Twitter page. This case study was drawn from two classes where students had taken the same course for a semester. Undergraduate students or graduate students from other departments and disciplines or courses were not recruited.

This study was initiated at a co-educational public university of about 9,000 students in the mid-southern United States. There were about 8,000 undergraduate students, and 1,000 graduate students as of 2013. For this study, two online graduate education classes titled "Teacher Leader I: Introduction to Educational Research" were chosen and all students enrolled (i.e., 42 participants) were invited to participate in the study. Twitter was used as a supplement in addition to the course learning management system, Moodle.

\section{B. Procedures}

The researcher obtained an approval from the Institutional Review Board (IRB) for this project. The procedures of this study involved the following three steps: First, a course Twitter page was developed at the beginning of the course and implemented in the class with policies and procedures for use. Second, the students were required to write reflection papers at the end of the semester. Course reflection papers and tweets collected from the Twitter page were analyzed using charting and theme analysis. In their reflection responses, students were instructed to reflect on the reading materials and instructional media (video clips, websites and other resources) used during the course. The average length of the essay was one and half page. Of 42 course participants, 27 participants wrote about their experiences of using Twitter (in addition to their experience of using other research tools such as drop box and survey monkey websites); 15 participants did not mention their Twitter experiences in their essays (but reflected on other course materials). Third, an online survey questionnaire was administered at the end of the semester to examine their experiences of using Twitter.

All participants tweeted to course Twitter pages for 16 weeks. The researcher analyzed all collected qualitative data (written responses, tweets, and survey data) separately. Written responses and tweets were evaluated using the document analysis technique. Both student responses and tweets were categorized into groups according to their relationships or themes. In other words, materials were sorted by categories, identifying similar phrases, patterns, relationships, and commonalities (Creswell, 2012; Schreier, 2012). The researcher evaluated quality and appropriateness of contents of these tweets and written responses in relation to the course syllabus (Educational Research). The process of analyzing responses consisted of identifying significant statements, sentences, or quotes that conveyed participants' experiences from the Twitter page and written responses submitted during the semester. Such information was categorized based on themes for analysis (Creswell, 2012). While analyzing data, the researcher mainly used percentage and some demographic information. Conclusions were then drawn based on: 1) the individual and collective responses of the participants' Twitter experiences, 2) content analysis of tweets, and 3) the responses received from a brief online survey.

Journal of the Scholarship of Teaching and Learning, Vol. 15, No. 2, April 2015. 
Bista, K.

\section{Role and Perspective of the Researcher}

At the time of this study, the researcher had general information about Twitter but had not used it for the classroom purpose. The researcher had a personal Twitter account used rarely to share information with friends. Twitter was selected for the classroom purpose over several other social media sites (compared to LinkedIn, Facebook, and Pinterest) because it has manageable applications and privacy settings. The researcher selected Twitter because of its simple application. Compared to multiple options available on Facebook, Twitter was an ideal tool to use among graduate participants who were also full time employees in the K-12 school settings at the time of this study.

The researcher taught in the college of education at the university where the study was conducted. The researcher had experiences of teaching online courses but never used Twitter as a course teaching tool before. The researcher used the course Twitter page for two sections of his/her online graduate course titled "Introduction to Education Research." Because of the online nature of the course, both the course participants and the researcher did not have any face-to-face interactions during the course. The researcher was open and flexible with the tweets posted by the course participants; however, students were required to post or re-tweet course related information weekly as the guidelines provided at the beginning of the semester in August 2013.

\section{Course Twitter Page}

The researcher, also course instructor, created a Twitter account following the link https://twitter.com/ and by filling out the required information (e.g., name, e-mail, password, department or college link, a brief bio). Then, the researcher selected the options under the profile setting which allowed the user to select whom to share information with and how to protect information from people outside of the class. Finally, the researcher invited the 42 course participants (i.e. all participants of the course) to join the Twitter class account via their school email address. Each course participant was required to post course related information weekly (i.e. video links, news related data and research, pictures, questions related to assignment, due dates and course announcements). The researcher also assigned a grade that would count towards the course final grade. Since this Twitter page was used for the online class, the researcher monitored the Twitter page at least twice a day for 15 weeks to ensure active participation of students, and quality of contents posted on the page. The course participants were asked to post complete and meaningful sentences instead of shortened text messages.

In this study, the researcher followed the guidelines, as offered by Dunlap and Lowenthal (2009) in their research, while using Twitter with graduate students in the online course:

a) The instructor of the course shared a purpose of using Twitter for the class to foster academically meaningful interactions.

b) The instructor defined expectations for course participations to share their tweets instead of designing it as a requirement. Students were asked to log into Twitter twice a week for fifteen weeks to share/update course related information.

c) The instructor presented an active participation in Twitter by tweeting current information about the course, by asking questions, and by sharing resources in the area of student interests. 
d) The instructor asked students to continue their presence in the Twitter community after courses are completed in December 2013 to build their own professional and academic connections with friends, peers, and professionals.

\section{Findings}

The findings (from the participants' written responses, the brief questionnaire, and the course Twitter page analysis) indicated that Twitter was a meaningful learning experience for all course participants. There were 2,414 tweets collected from 40 participants by the end of the semester. Of 42 participants, two participants became inactive as they dropped the course. In the online questionnaire administered at the end of the semester, only 27 members participated. The following sections will describe a) the written responses of 27 participants regarding their perceptions of Twitter use, b) the 27 responses collected via brief online survey, and c) the selected 2,414 responses from the course Twitter page.

Qualitative data analysis revealed the following themes relating to academic practice and activities of Twitter among graduate students. These are described below using illustrative tweets. Twitter identifications were edited to maintain participant anonymity.

\section{Table 1}

Graduate Students' Twitter Usage in Academic Activities

\begin{tabular}{|c|c|c|}
\hline Theme & Theme description & $\begin{array}{l}\text { Example of student written } \\
\text { responses or tweets }\end{array}$ \\
\hline $\begin{array}{l}\text { Change in } \\
\text { students' } \\
\text { perspectives }\end{array}$ & $\begin{array}{l}\text { Uneasy experience to sign up for a course } \\
\text { Twitter page; total surprise; fun to use and } \\
\text { very helpful }\end{array}$ & $\begin{array}{l}\text { "...I will admit that I thought it was } \\
\text { a waste of time." }\end{array}$ \\
\hline $\begin{array}{l}\text { Professional } \\
\text { value }\end{array}$ & $\begin{array}{l}\text { Developed professional network among } \\
\text { peers and professor; wanted to use beyond } \\
\text { classroom; shared information and } \\
\text { resources with peers }\end{array}$ & $\begin{array}{l}\text { "I enjoyed the quick responses in } \\
\text { which questions were answered..." }\end{array}$ \\
\hline $\begin{array}{l}\text { Academic } \\
\text { learning } \\
\text { experience }\end{array}$ & $\begin{array}{l}\text { Learned how to tweet, seek course related } \\
\text { information to post on the Twitter page; } \\
\text { found difficulty in using; asking for and } \\
\text { providing support to others }\end{array}$ & $\begin{array}{l}\text { "I had never used Twitter before this } \\
\text { course. I look for videos or } \\
\text { interesting things to post on Twitter } \\
\text { often" }\end{array}$ \\
\hline $\begin{array}{l}\text { Challenges } \\
\text { while using } \\
\text { Twitter }\end{array}$ & $\begin{array}{l}\text { Signed up for the first time; difficult to } \\
\text { keep up with course related materials; } \\
\text { found challenging }\end{array}$ & $\begin{array}{l}\text { "It was a little difficult to remember } \\
\text { to check it and most on it from week } \\
\text { to week." }\end{array}$ \\
\hline $\begin{array}{l}\text { Student } \\
\text { engagement }\end{array}$ & $\begin{array}{l}\text { Used to ask questions, led discussion; } \\
\text { shared quick and constant feedback; kept } \\
\text { updated with each other; interactions; like } \\
\text { and dislikes }\end{array}$ & $\begin{array}{l}\text { @ariel2: Bias, bias everywhere! } \\
\text { Reading Ch. } 8 \text { has made me realize } \\
\text { how hard it is to get a truly } \\
\text { representative sample of a } \\
\text { population. } \\
\text { @bernarjn: I just posted my } \\
\text { questions under Group A. I hope to } \\
\text { hear from my group soon! }\end{array}$ \\
\hline
\end{tabular}


Bista, K.

\section{A. Themes Emerged from the Student Written Responses}

The majority of the course participants, at the time of signing up for the course, did not expect the instructor would use Twitter as one of the required activities throughout the semester. As the instructor and the participants did not have much experience of using Twitter as a learning tool, the majority of participants in this study expressed their first encounter with Twitter in this class. They shared their first experience of setting up an account for Twitter, what to post, how often to post, and how it works overall. As a majority of course participants were school teachers, administrators and instructional technologists in the public school systems in the US, they were not considering the value of Twitter as a classroom tool.

\section{B. Change in the Perceptions}

Participants were surprised to use Twitter in the graduate research class. At first, they expressed uneasy feelings about signing up for a course Twitter page and tweeting the information that counted for the course grade. Adele Hardman, an MEd student in Curriculum and Instruction, wrote how her perceptions of using Twitter changed over the course:

Who would have ever thought it would have been a class requirement to have a twitter account? I sure would not have. It definitely caught me by surprise. Since social media has such a large influence on today's society, I thought it was an awesome way to get all the participants involved. It was a great way for us to share current news related to our study and educational happenings with our colleagues. It was interesting to see the different perceptions and thoughts others had on the hot topics, such as Common Core State Standards, of the educational world.

Like Adele, another course participant also expressed her discomfort with using Twitter initially and how it became a useful tool later:

When I first found out that the course had a Twitter page that we were required to comment on at least twice a week, I will admit that I thought it was a waste of time. As the course has progressed I have come to love the course Twitter page. This page allows the students to communicate with and receive feedback from the professor very quickly. It is also beneficial that all the members of the class can see both the question that was posed and the response that was given. I will admit that this is my favorite part of the Twitter idea, because my classmates often have some of the same questions that I do and rather than the professor having to answer the same question forty-five different times, he only has to answer it once and everyone that visits the page can see it. Overall I believe that the Twitter page was very beneficial and would love for some of my other professors to follow suit and create class Twitters.

(Aileen Linder, MEd in Educational Leadership)

Although many course participants were first time Twitter users in the online graduate course, these participants soon realized the benefits of their presence on the Twitter page. Alice Plauche, an MEd student in Reading wrote, "Twitter has been a lot of fun to use and very helpful. It served as a more personal form of gathering information and seeing what other people are interested in. This was a great idea for this class because it allowed us to communicate 
through social networking, which is extremely popular in today's time." As the instructor posted important announcements on the course page and fellow classmates started posting interactive discussions, participants of the course gradually saw changes in their original perceptions. Allison McCormick, another MEd student in Instructional Leadership shared, "Using twitter for this course helped me. I enjoyed reading all the comments and posts of research articles and videos. I learned a lot about different topics in education and seeing the views of students in our class. I think using twitter is a good idea." Course participants reported that they enjoyed not only posting current information on the course Twitter page, but also staying in touch with their fellow classmates:

When I think of Twitter, I never thought of it as being a learning tool. I was initially apprehensive about using this type of social media for a class, but I quickly realized how beneficial it was. I believe that our course Twitter is an effective and efficient way to communicate soundly amongst each other in an unconventional manner. Fellow classmates and I were able to share our thoughts and words in 140 characters or less. The unique quality about our course Twitter is that we're using one of the most popular networking tools in today's society as a central location to share educational information for this course. For me, being able to connect with fellow classmates via twitter allows me to not only interact with them about current topics, but embrace their thoughts and ideas as well.

(Amanda Armstrong, MEd Candidate in Reading)

\section{Professional Value}

As an instructor of the course, the researcher was interested in exploring whether the course participants would see a professional value of Twitter in higher education or other school settings or for developing a professional network among peers and colleagues. A few participants of this study shared their positive views regarding the usage of Twitter in professional development. Arthur Hobson, MEd student in Educational Leadership suggested, "Twitter has been very interesting to see all the different classmates' works, surveys, and comments. This has allowed me to learn about a new tool for educators to use for instruction. Maybe not in middle school, but definitely could be a tool for high school students." Another participant, Ariel Smith, MEd in Instructional Technology saw the value of Twitter in her personal growth: "I have also continued to interact with my classmates on Twitter and completed some outside reading assignments."

Like Arthur and Ariel, another graduate student in Educational Leadership, Amy Willis, noticed the use of Twitter at a different level, and was interested to experience it personally in her professional development:

I have really enjoyed following my classmates and reading and responding to their posts and links to articles. My principal actually runs an account for our school where he tweets educational articles, posts, and updates related to our school and the educational field. We have many parents that follow the school, and I think that is really neat! I have also began to follow many other educational leaders and bloggers to stay up to date with important information that I am unable to attend, such as major educational conferences across the US. I probably spend a little too much time on Twitter reading educational information, but hey, you can never read or learn too much, right? 
Bista, K.

Anastasia Griffin, an MEd student in Special Education who was taking this online class from South Africa, shared her adventure of using Twitter and Facebook in the course, and that now her school in South Africa has also opted to use Twitter as a communication tool:

I have been pleasantly surprised to find that I enjoyed the social networking part of this class. Not having been one to be much on my husband's Facebook account (until this class I never had my own), and never having any desire to open a Twitter account, I've found it fairly remarkable to learn their true value in education. Twitter has been very useful; I've felt in prompt communication for our class. It's easy for me to see how easily that knowledge could be transferred to my Facebook site as well. Interestingly, the International School of Ouagadougou has, at the same time, determined that both FB and Twitter will be helpful communication tools for the school.

Angela Sirius, an MEd in Curriculum and Instruction, enjoyed the course Twitter page setting that allowed only the course participants to share their information and was looking forward to using a Twitter page in her school for the parents of her first grade students:

Twitter has been a great way to get my thoughts out to others in the class quickly and efficiently! I have loved reading articles that a classmate or professor link to a tweet from my smart phone. I have been doing a little research about Twitter in the classroom, because I am interested if it would be a good way to communicate with the parents of my first graders. I like how we were only allowed to add people that are in our class, and that is what I would have to do if I opened it to my parents. There are lots of times in the day that I would love to send a picture or link to something great we are doing in the classroom. I like that it is instant! I often take pictures with my camera or phone, but it may end up being a couple of days or weeks before I get it to my parents.

Similarly to previous participants, Angela Hathaway, an MEd in Educational Leadership program, shared her learning experience, and usefulness of Twitter in her personal life:

I believe I may have mentioned my hesitancy with using the social media site before, and it mostly stems from lack of familiarity with the site and-quite honestly-general absence of interest in the structure of the source. With Twitter, I actually had to train myself to stay concise and remain focused on the main idea. In the long run, that could probably help me out quite a bit, especially since many papers I've written have always wanted me to "get to the point." That's exactly what Twitter encourages. I will say that I find Twitter much cleaner and focused, whereas Facebook tends to get lost in advertisements and useless information most of the time.

As most of the course participants in this study were classroom teachers, they were asked "What value, if any, do you think Twitter can provide to a course?" All participants shared positive attributes of Twitter if used properly in the class. Some of the selected responses are listed below:

"Keep up to date information and interactions with classmates/teachers."

"I think it can create a central point for people to communicate and see other communications easily."

"Twitter adds the value of quick communication between classmates and the professor."

"I think it provides a great value. It is a good way to socially connect with others on a professional level." 
Bista, K.

"Great tool connect with the course materials especially in the online courses."

"Twitter can increase communication among classmates and instructors due to its easy use format."

"Twitter was helpful to link others to important topics, articles, videos, etc."

"I enjoyed the quick responses in which questions were answered. I also find the quick access to educational material through links to be very useful."

\section{Learning Tool or Learning Experience?}

Some participants perceived Twitter as stressful while others took it as a learning experience. As a course instructor, often the researcher was looking for a better way to manage the tweets, by themes or topics, or ways to avoid unwanted side advertisements throughout the 15 weeks of the course. The course participants reported the use of Twitter as a learning experience instead of an effective learning tool for the class:

I had never used Twitter before this course. I look for videos or interesting things to post on Twitter often. I become so engrossed in my findings sometimes that I forget to post them on Twitter. I find myself emailing other teachers or parents that I feel my findings might be relevant. I have learned quite a bit while in search of my next tweet.

\section{(Anna Evans, MEd Special Education)}

I was really nervous about this course when I read the first assignment, and discovered I had to create and utilize a drop box and twitter account. I usually steer clear of any activities including technology, because I lack all self confidence in the department of the "cyber world". I have even put off obtaining my master's degree, because I lacked the time to take traditional classes, and was too intimidated to pursue online courses. This year alone, I have accomplished taking four online courses, and setting up two drop box accounts, plus one twitter account.

\section{(Anita Spears, MEd Middle School)}

All course participants were graduate learners taking an online course, and this class was one of the first required courses in their master's degree in various concentrations. A few participants in the study reported difficulty using Twitter. After their semester long participation in Twitter, three participants did not see the value of using Twitter as a learning tool but shared their positive learning experience at the end of the semester:

Twitter has been an issue for me since the beginning. I have never really used Twitter and am still getting used to it. I do not check as much as I probably should but rely more on Moodle and forums for my information. Twitter confuses me and I find it hard to find other participants' feedback and responses. I still post weekly on this application and hope to grow more in understanding how to navigate and develop a more usefulness for this tool in the future.

(Annabel Bernard, MEd Early Childhood)

The Twitter assignment was the most challenging for me because I wasn't used to social media such as Twitter. I've never had a Twitter account nor was I ever 
Bista, K.

interested in signing up. However, once I signed up ...it certainly wasn't hard. It forced me to be more aware of articles relating to the class or education, which I thought was very helpful. I did find the Twitter assignment very useful because it allowed a sense of connection with the class participants.

(Allan Cunningham, MEd English as a Second Language)

Like Annabel and Allan, Angie Thomas, an MEd student in Special Education summarized her experience, "Twitter, I never thought that I would ever use it but, now I'm glad that I learned how to do it."

\section{E. Challenges While Using Twitter}

Participants shared a variety of reasons of why they struggled using Twitter for their required graduate class. First, participants signed up for the first time, requiring them to post certain educational information, and they lacked familiarity with the tools. Second, those participants who use Facebook reported having a different experience of using the limited space (140 characters) to share educational information with their peers and instructors. Third, a few participants said they were uncomfortable keeping up with Twitter regularly along with their busy full time schedule and course materials as a graduate student. Finally, the pre-conceived negative attitude of a few participants toward Twitter was another contributing factor to difficulty navigating the course Twitter:

The most difficult part of the course for me was to keep up with Twitter. I did not use twitter before the course and it was a little difficult to remember to check it and post on it from week to week. Also, I found it a little difficult to use and would miss tweets and re-tweets from people. I think that creating a course Facebook page would be a great way to incorporate social media into the course since most people use it and check it very often.

(Alexis Ellis, MEd Elementary Education)

I had a hard time catching on to how to use Twitter and beginning my research. I was strongly against having a Twitter account prior to this course. With this negative attitude it was hard to navigate around and I was very unsure of how to use it.

(Andrea Nettles, MEd English Education)

Twitter for me was an extra headache, as I was not previously signed up for twitter and had to create an account specifically for this course. Twitter is intended to be quick snip-bits of information, and thus the character count is limited to 140 characters per tweet. I did not have the desire to previously use twitter and still, often do not check for tweets. At this particular moment, I'm actually thinking to myself, "Did I send enough tweets to qualify for the full participation grade?"

(Alfred Helphenstine, MEd English as a Second Language)

Journal of the Scholarship of Teaching and Learning, Vol. 15, No. 2, April 2015. 


\section{F. Student Engagement and Likelihood to Use in the Future}

Participants engaged in the course Twitter page in a variety of ways. Some shared information they enjoyed while reading course related materials such as journal articles or textbook. Others posted their dislikes to their peers and instructors. A majority of responses indicated that students used Twitter to ask questions about the class discussion or assignments as they received quick reply either from their fellow students or the teacher.

Data received from a brief online survey showed that 93.2 percent of participants agreed, "I used Twitter to get a quick response related to class project or research," whereas 3.8 percent did not agree. In another statement, 96.1 percent of participants said, "I used Twitter to discuss course readings," and 3.8 percent did not agree. Finally, 66.1 percent of participants reported, "I used Twitter to share ideas/information related to course with peers," and 33.9 percent disagreed.

The researcher also asked whether these participants will use Twitter in the near future. The participants indicated that Twitter is a useful tool in the classroom. Eighty percent indicated they are going to use in their work place and 23 percent have no plans. Ninety percent of participants are going to utilize Twitter to network with their friends and colleagues but 7.7 percent indicated they are not going to use it. Eighty five percent of participants reported that they are planning to use Twitter to communicate with teachers and 15.4 are not. Similarly, 92.4 percent of participants indicated that Twitter is a learning tool in the class whereas about 8 percent reported that it is not a learning tool.

As seen in survey data, students' written responses suggested that some participants were likely to use it for their professional development, whereas a few respondents were not. For instance, one participant said she is going to use Twitter for her personal purpose:

Twitter was new to me.... But, this class has shown me that Twitter doesn't have to be a thoughtless bragging message board. It can actually be a place of thoughtful discussion, easy webpage and article sharing, and a place to bounce ideas off of one another. While I don't think I'd use this in the classroom with students, I do think I'll continue to follow professionals in the field of education to just stay in tuned with what is currently going on and get insight on what people are thinking.

(Antonia Herr, MEd in Educational Technology) Another participant also shared her personal reason of not using Twitter this way: I am not really enjoying the Twitter assignments because I am not a fan of social media. I am a more private person than most people and do not like to put my every thought on the internet. Putting things on Twitter is more of a chore for me and not something that I will continue to do after this course if it's not necessary for another course.

(Amber Rome, Elementary Education)

\section{G. Themes Emerged From Content Analysis of Tweets}

In this section, the researcher included information received from the course Twitter page. Course participants tweeted twice a week for fifteen weeks per the course Twitter page guidelines. By the end of semester, there were 2,414 tweets from 40 participants. The information collected from the course Twitter page is organized in the following themes: 
Questions. Participants were asked questions related to the course materials, assignments and general information using the course Twitter page. Most of the course participants were school teachers and administrators. They posted questions about how information they learned in the class can be used professionally in their everyday lives. Participants provided immediate responses, if the course materials (such as video clips, website links or audio file) did not work on their computers. The following sample tweets represented student engagement in asking questions:

Anna Molly@Anna114: so allwe have left is the research paper?

Alexis Mathis@AlexisMathi: Whatdoyou think the challenges will be for testing Students with Disabilities on the Common Core Curriculum?

AssayHerr@sayherrgrn: Is there a point where too much extra-curricular or after school activities hinder academic performance?

AgathaLong@Long10: I've read the research samples. Wondering if I can tie ideas from my own class that relates to the course?

AmyWillis@amywillis: My school is asking teachers to take in studentswhen other teachers are absent...because there is a sub shortage...thoughts?

Adeline Love@lovewl: I can't open the file with the final research paper video. Anyone else having trouble with this?

Discussion. Participants started several discussion threads on the course Twitter page on a variety of topics such as common core standards, professional developments, course materials, and their individual research topics. The instructor asked students to start these types of discussion threads. Based on the needs and interests of the participants, they started these threads. At times additional information was added to clarify information or to summarize the case that was provided. In some of the discussion posts, students shared the concepts that they differentiated and understood, and even suggested to their fellow classmates. Some of the sample discussion items are listed here:

AlbertaWhite@whitesv: I loved this journal [article]! http://bul.sagepub.com/content/90/2/87 Teacher Leaders and collaboration are a must!

Annabel Bernard@bernara: The article reviewwas a very interesting and eye-opening assignment. Had fun with this one :-)

Ariel Smith@ariel2: Bias, bias everywhere! Reading Ch.8 has made me realize how hard it is to get a truly representative sample of a population.

AmyWillis@amywillis: Performance-base pay scales: How will the new performance-based teacher pay scale affect teachers? Positively? Negatively?

Assessment. Participants shared quick and constant feedback related to instructional materials such as PowerPoint, video clips, and selected articles as helpful or not helpful. In addition, participants also shared their assessment of information posted by other course participants. The selected samples of participants' tweets are as follows:

Angie Thomas@Mathis: Good power point on Qualitative research! I think that I understand it better.

Ariel Smith@ariel2: Impressed withmy classmates after reading some of their article reviews. Specially intrigued by the idea of teacher leaders.

AlexandraHensley@Hensley10: This video clarified the differences between quantitative and qualitative research and questions.

Aileen Linder@MissLinder: Things to do today: Research midterm and education quiz. I got this! :) 
Bista, K.

Allan Cunningham @Cunningh: I enjoyed the discussion question activity, it forces you to read, I'm going to try this with my 8th graders, because they are lazy

Annette Smith@smith3: The Chpt 2 power-point is very helpful. It gives a good overview of research process, I'm gonna save it so I can check back at the checklist

Updates. Students by nature want to keep updated with each other. When a member updates his or her status, in any social network, it helps another individual understand what is going on. Course participants' updates were perceived as positive reinforcement. Any information related to course topic, reading assignment or expectation of the instruction would be helpful and may convey a powerful message to each other. Participants shared their updates in the following ways:

AngieThomas@Mathis: I finally finished my literature review! Yea!

AdaBrown@brown77:Dr. is the bomb. Reflection 2 was submitted and graded within 10 minutes...Oh how I love this class

AdrienneEvans@abc28: http://www.youtube.com/watch?v=SwzfgNWmR6E ... Found this video a little while ago about John Elder Robison and Asperger syndrome. One day I hope to read his book.

Agnes Masters@masters: Interestingly enough, the researchers found that a principal's instructional practices do not affect student growth.

Retweeted by AmyWillis@Wills: Arne Duncan@arneduncan: NewTEACH documentary airing tonight shows just how challenging and rewarding teaching can be: http://www.takepart.com/teach

Arthur Hobson@hobson: Just finished midterm exam. Anxious to see my grade. Assy Herr@sayherrgrn: Did mine yesterday. She grades pretty quickly. Hope you nailed it! I did :)

Alfreda Huskey@huskey: chapter 7 historical research is my favorite. I am a huge history fan and love reading research on history.

AgathaLong@Long10: The article I summarized was based on single sex genders in the classroom

Annabel Bernard@bernarjn: I just posted my questions under Group A. I hope to hear from my group soon!

\section{Discussion}

This study presented the perspectives of graduate students' (from Master of Education programs) experiences of using Twitter as a pedagogical tool for 15 weeks as a required social media activity in the class. Participants reported that they used Twitter for the first time. Participants also reported their positive experiences of engaging in class discussions, group projects, course announcements, and other required activities in their graduate online education programs.

Participants acknowledged that Twitter fostered an active collaboration and student participation in continuing their educational activities (e.g., assignments, projects, and announcements) (McArthur \& Bostedo-Conway, 2012). However, participants shared various personal reasons for why it was a challenge for them to use Twitter in the course- ranging from limited knowledge of Twitter to uninterested users who did not see its wider application in academia-whether in the K-12 settings or higher education. Researchers indicated that it is complex to define such academic pursuits and identities (Blair, 2013; Junco at el., 2011; Lin, Hoffman, \& Borengasser, 2013). Twitter is beneficial to both professional and personal lives

Journal of the Scholarship of Teaching and Learning, Vol. 15, No. 2, April 2015. 
(Lalonde, 2011), including educational domains (Hytten, 2010; Junco, Elavsky, \& Heiberger, 2013).

The experiences of students and instructors varied while using Twitter in the regular and online Master of Education course. Participants not only reported challenges while using Twitter but also expressed an interest in future endeavors. However, the factors such as "age of students, number of students, and nature of classroom setting and technological knowledge of students can be some of the variables that the teacher has to consider while using Twitter in the classroom" (Bista, 2014, p. 145). Similarly, as Bista (2014) mentioned, the use of Twitter may not change the conventional academic literacy practices, but it certainly invites students to participate in the learning process. As Al-Khalifa (2010) mentioned, Twitter for this course became a virtual office where the researcher had a synchronous communication with the course participants. Overall, the findings from the current study suggest Twitter is a useful tool to enhance the social presence of students (Dunlap \& Lowenthal, 2009).

\section{Conclusion}

This is one case study based on the perceptions of graduate students in education discipline where participants shared their experience of using Twitter as a required tool throughout a semester. The participants, professional graduate students working full time in the K-12 school settings, reported a variety of experiences - many of them did not realize Twitter was a learning tool worthy enough to implement in the graduate class; some of them found it challenging to follow up their tweets and information to posts owing to their busy schedule; a few of them found Twitter helpful to engage with course materials; some of them even implemented Twitter in their personal and professional setting during the course; and many of them learned how to use Twitter and found their perceptions had positively changed.

Overall, participants in the current study reported positive experiences, saw Twitter as a valuable tool to use in the classroom, and recommended it to use in the future classes with clear instructions and expectations. Although there are clear debates between the educational rhetoric and the use of social spaces (e.g., Twitter, Facebook, and LinkedIn), the careful and creative use of such social media can strengthen the educational interest and academic success of students (Bista, 2014; McArthur \& Bostedo-Conway, 2012). Twitter is rich in engaging students and teachers, and educators across the disciplines (Morgan, 2014).

This study may not be generalizable to a larger audience because the usage of Twitter was limited to a small sample size from one university class. Perceptions of graduate students (who were employed at the time of taking this online course) may vary if the participants were full time graduate students or students taking face to face classes. Only two course participants were familiar with Twitter before the course but the rest of the course members did not use twitter in their personal or professional lives. Participants might have different experiences if they were familiar with Twitter before the class started. In the context where there was not a clear social media policy in public schools in the United States, and these working participants naturally had a narrowed views of using Twitter in the class. Participants from another culture or geographical location might have different views and responses if this study would be replicated. The major limitation of the current study was data were collected from two small online classes and the online questionnaire and written responses from the course participants. The finding, therefore, does not generalize to students from a different program or setting. 
Bista, K.

Although participants of this study indicated positive experiences of using Twitter, and recommended to use it in the future classes, this activity was required as outlined in the course. Participants had to participate in the activities in order to earn the points that counted towards their final course grade. The validity of the perceptions of course participants was not held against those who shared their experiences of Twitter use. This study heavily relied on the perceptions of the participants who shared their views in the course reflection essays as well as in the brief online survey. The grade expectations might or might not have influenced the opinions of the participants.

Twitter may be used differently in online teaching than in a traditional classroom setting. Some important elements such as the background of students (e.g., age, number of students), nature of the classroom setting, nature of course information and technological knowledge of students may be worth consideration while implementing Twitter in the classroom. It is hard to determine the facts about whether Twitter helps students build intellectual growth when used in the classroom or to develop a brand for marketing and other purposes. There are no definite answers about whether Twitter has been creating more social and educational opportunities for scholarly practice (Bista, 2014). However, Twitter is one of the emerging online spaces for social and educational participation and it needs future inquiry for other possibilities.

\section{References}

Al-Khalifa, H. S. (2010, May). Finding a place for Twitter in higher education. eLearn. Retrieved from http://elearnmag.acm.org/archive.cfm?aid=1821980

Antlfinger, C. (2014, January 24). Twitter gaining acceptance as a classroom tool. The Washington Times. Retrieved from http://www.washingtontimes.com/news/2014/jan/24/twittergaining-acceptance-as-a-classroom-tool/print/

Aspden, E. J., \& Thorpe, L. P. (2009). Where do you learn? Tweeting to inform learning space development. EDUCASE Quarterly, 32(1). Retrieved from http://www.educause.edu/ero/article/where-do-you-learn-tweeting-inform-learning-spacedevelopment

Bart, M. (Ed.) (2011). Social media usage trends among higher education faculty: Faculty focus special report. Madison, WI: Magna Publications, Inc.

Bista, K. (2014). Twitter in higher education: New pedagogy in the knowledge era of globalization. In M. Limbu \& B. Gurung (eds.), Emerging pedagogies in the networked knowledge society (pp. 195-205). Hershey, PA: IGI Global Publications. doi: 10.4018/978-14666-4757-2.ch010

Blair, A. (2013). Democratizing the learning process: The use of Twitter in the teaching of politics and international relations. Politics, 33(2), 135-145. doi: 10.1111/1467-9256.12008

Chichester, K. (2010, August 27). Cross-county collaboration: It all started with Twitter. National Writing Project. Retrieved from http://iditalis/nwp.org/resource/716 
Bista, K.

Creswell, J. W. (2012). Qualitative inquiry and research design: Choosing among five approaches (3rd ed.). Thousand Oaks, CA: Sage.

Dunlap, J. C., \& Lowenthal, P. R. (2009). Tweeting the night away: Using Twitter to enhance social presence. Journal of Information Systems Education, 20(2), 129-135.

Ebner, M., Lienhardt, C., Rohs, M., \& Meyer, I. (2010). Micro-blogs in higher education: A chance to facilitate informal and process-oriented learning. Computers and Education, 55, 92100. doi: 10.1016/j.compedu.2009.12.006

Faculty Focus. (2009). Twitter in higher education: Usage habits and trends of today's college faculty. Madison, WI: Magna Publications, Inc.

Faculty Focus. (2010). Twitter in higher education 2010: Usage habits and trends of today's college faculty. Madison, WI: Magna Publications, Inc.

Galagan, P. (2010). Ready or not? Training and Development, 64(5), 29-31.

Garrison, D. R., Anderson, T., \& Archer, W. (2000). Critical inquiry in a text-based environment: Computer conferencing in higher education. The Internet and Higher Education, 2(2), 87-105.

Gouseti, A. (2010). Web 2.0 and education. Learning, Media and Technology, 35(3), 351-356. doi: $10.1080 / 17439884.2010 .509353$

Grosseck, G., \& Holotescu, C. (2008). Can we use Twitter for educational activities? The 4th International Scientific Conference eLSE: eLearning and Software for Education. Retrieved from http://adl.unap.ro/else/

Hytten, K. J. (2010). Facebook's contribution to educationally purposeful activities and college student engagement (unpublished doctoral dissertation). University of Vermont, Burlington.

Johnson, R. B., \& Christensen, L. (2014). Educational research: Quantitative, qualitative, and mixed approaches $\left(5^{\text {th }}\right.$ ed.). Thousand Oaks, CA: Sage.

Junco, R., Elavsky, M., \& Heiberger, G. (2013). Putting Twitter to the test: Assessing outcomes for student collaboration, engagement and success. British Journal of Educational Technology, 44(2), 273-287. doi: 10.1111/j.1467-8535.2012.01284.x

Junco, R., Heiberger, G., \& Loken, E. (2011). The effect of Twitter on college student engagement and grades. Journal of Computer Assisted Learning, 27(2), 119-132. doi: 10.111/j.1365-2729.2010.00387.x

Kirschner P. \& Karpinski A. (2010) Facebook and academic performance. Computers in Human Behavior 26, 1237- 1245. doi: 10.1016/j.chb.2010.03.024 
Bista, K.

Lalonde, C. (2011). The Twitter experience: The role of the Twitter in the formation and maintenance of personal learning network (Master's thesis). Royal Roads University, Canada.

Lang, J. M. (2013). How Orwell and Twitter revitalized my course. The Chronicle of Higher Education. Retrieved from https://chronicle.com/article/How-OrwellTwitter/142617/

Lin, M. F., Hoffman, E. S., Borengasser, C. (2013). Is social media too social for class? A case study of Twitter use. TechTrends, 57(2), 39-48.

Luttrell, R. (2012). Social networking sites in the public relations classroom: A mixed methods analysis of undergraduate learning outcomes using wordpress, facebook, and twitter (unpublished doctoral dissertation). California Institute of Integral Studies, San Francisco, CA. UMI No. 3539719

Malesky L. A., \& Peters C. (2013). Defining appropriate professional behavior for faculty and university students on social networking websites. Higher Education, 63(1). doi:

10.1007/s10734-011-9451-x.

McArthur, J. A., \& Bostedo-Conway, K. (2012). Exploring the relationship between studentinstructor interaction on Twitter and student perception of teacher behaviors. International Journal of Teaching and Learning in Higher Education, 24(3), 286-292.

Matteson, A. (2010). Tweacher: The Twitter enhanced teacher. School Library Monthly, $27(1), 22-23$.

Mertens, D. M. (2015). Research and evaluation in education and psychology (4 ${ }^{\text {th }}$ ed.). Thousand Oaks, CA: Sage.

Morgan, H. (2014). Focus on technology: Enhancing instruction and communication with Twitter. Childhood Education, 90(1), 75-76. doi: 10.1080/00094056.2014.872522

Priego, E. (2011, Sept. 11). How Twitter will revolutionize academic research and teaching. The Guardian. Retrieved from http://www.guardian.co.uk/higher-educationnetwork/blog/2011/sep/12/twitter-revolutionise-academia-research

Rockingson-Szapkiw, A. J., \& Szapkiw, M. (2011). Engaging higher education students using Twitter. Proceedings of Global Learn Asia Pacific, 360-364. Retrieved from http://works.bepress.com/amanda_rockinson_szapkiw/31/

Salter, A. (2012 October 8). Presenting for Twitter at conferences. The Chronicle of Higher Education. Retrieved from http://chronicle.com/blogs/profhacker/presenting-for-twitterat-conference/43176

Schreier, M. (2012). Qualitative content analysis in practice. Thousand Oaks, CA: Sage.

Journal of the Scholarship of Teaching and Learning, Vol. 15, No. 2, April 2015. 
Bista, K.

Springer, T. J. (2014). UD faculty use Twitter to enhance classroom experience. Retrieved from http://www.udel.edu/udaily/2014/nov/tech-classroom-twitter-111913.html 1/

Veletsianos, G. (2012). Higher education scholars' participation and practices on Twitter.

Journal of Computer Assisted Learning, 28, 336-349. doi:10.111/j.1365-2729.2011.00449.x

Vooren, C. V., \& Bess, C. (2013). Teacher tweets improve achievement for eight grade science students. Systemic, Cybernetics, and Informatics, 2(1), 33-36.

Yuan, H. (2012). Applying Twitter to EFL reading and writing in a Taiwanese college setting (Doctoral dissertation). Indiana State University, Indiana.

Yin, R. K. (2013). Case study research: Design and methods $\left(5^{\text {th }}\right.$ ed.). Thousand Oaks, CA: Sage. 